\title{
STUDY ON DEFORMABILITY OF REACTIVE POWDER CONCRETE WITH STEEL MESH
}

\author{
${ }^{1}$ Dvorkin L.I., Doctor of Engineering, Professor, \\ dvorkin.leonid@gmail.com, ORCID: 0000-0001-8759-6318 \\ ${ }^{1}$ Bordiuzhenko O.M., Ph. D., Associate Professor, \\ bord@nwm.edu.ua, ORCID: 0000-0003-3686-5121 \\ ${ }^{1}$ National University of Water and Environmental Engineering \\ 11, Soborna street, Rivne, 33028, Ukraine
}

\begin{abstract}
Reactive powder fiber-reinforced concrete has sufficiently high boundary deformation properties. However, further increase in these properties is difficult. This is explained by the complexity of the oriented arrangement of the steel fiber in the concrete array in parallel with the tensile stress and by the inability of individual fibers to work together.

Increasing the values of the deformation properties of concrete, such as the tensile strength and the ultimate deformation of concrete can be achieved by using as a disperse reinforcing component, steel meshes, which are placed in the concrete perpendicular to the acting load (parallel to the tensile stress). Steel meshes in the mass of concrete act as analogues of fiber, but, in contrast, have two significant advantages: they allow the joint operation of the entire volume of steel under stresses and are also characterized by the correct orientation relative to the existing external load. As a result, it is possible to increase the tensile strength of concrete and increase its plastic deformation significantly.
\end{abstract}

Keywords: reactive powder concrete, dispersed reinforcement, steel meshes, fiber, deformability.

Introduction. The deformability of building materials, in particular concrete, their ability to resist mechanical influences largely depend on the flexural tensile strength. For concrete and reinforced concrete structures, this index, as well as the ability to perceive load without loss of bearing capacity can be provided in various ways, based on the increase of deformation-plastic properties.

Analysis of recent researches and problem statement. There are various ways to increase the deformability of concrete. One way to increase the deformation properties of concrete is to impregnate concrete with various polymeric substances [1] or to introduce them into concrete mixtures [2-3]. Thus formed concrete polymers or polymer cements are characterized by increased flexural tensile strengths of $2 \ldots 3$ times as compared to the original concrete and correspondingly increased marginal deformations. However, the disadvantage of this method is the complexity of the technology associated with the need to pre-dry cured concrete and its subsequent impregnation (preferably under vacuum) for several hours with polymeric solutions or monomers, which are subsequently polymerized. In addition, the thermal stability of such concrete is significantly reduced.

Another well-known way of increasing the deformation properties of concrete is the introduction of 100 to $300 \mathrm{~kg} / \mathrm{m}^{3}$ of steel fiber into its composition [4-7]. Due to this, the tensile strength in bending of the thus formed fiber reinforced concrete increases by $3 \ldots 4$ times and reaches values of $15 \ldots 18 \mathrm{MPa}$, and the relative limit deformations increase by $2 \ldots 3$ times (up to $10 \ldots 15 \cdot 10^{-4}$ ). The disadvantage of this method is the complexity of the orientation of the steel fiber in the array of concrete in parallel with the tensile stress and the inability to ensure the joint work of individual fibers. This leads to inefficient use of the entire mass of the fiber and, as a consequence, the potential loss of the possibility of increasing the values of deformation properties, in particular plastic deformations.

Bulletin of Odessa State Academy of Civil Engineering and Architecture, 2020, no. 79, page 78-84 
An additional increase in the deformation properties of concrete to obtain material with high deformation properties can be achieved, in the so-called «reactive powder fiber reinforced concrete (RPFRC)»». The use of a concrete matrix with a maximum filler size of $1.25 \mathrm{~mm}$ and steel fiber in the amount of $150 \ldots 200 \mathrm{~kg} / \mathrm{m}^{3}$ is characteristic of such fiber reinforced concrete [8-10]. Due to the use of fine fillers in this method it is possible to achieve a greater homogeneity of the concrete matrix, which leads to an increase in flexural tensile strength to $20 \ldots 25 \mathrm{MPa}$ and values of boundary deformation to $15 \cdot 10^{-4}$.

However, for RPFRC, the achievement of high boundary deformation values is complicated by the need for an oriented arrangement of the steel fiber in the concrete array in parallel with the tensile stress and the inability of the individual fibers to work together.

Increasing the values of the deformation properties of concrete, in particular the flexural tensile strength and ultimate deformation of concrete can be achieved if used as a reinforcing component, steel meshes that are placed in the concrete perpendicular to the acting load (parallel to the tensile stress). Steel meshes can be considered as an analogue of the ordered dispersed reinforcement.

Research objective. Investigation of the possibility of increasing the deformation properties of concrete, such as flexural tensile strength and ultimate deformation by using steel meshes as a dispersed reinforcing component.

Materials and research methods. Reactive powder concrete (RPC) of the following composition was used, $\mathrm{kg} / \mathrm{m}^{3}$ : Portland cement class CEM I $42.5 \mathrm{R}-700$; ground sand (specific surface area $\left.=250 \mathrm{~kg} / \mathrm{m}^{2}\right)-360$; sand $(0.16 \ldots 1.25 \mathrm{~mm})-1130$; polycarboxylate type modifier Dynamon SP3 $-1.5 \%$. The water/cement ratio of mixture was 0.28 , the mixture workability provided slump cone of $25 \mathrm{~cm}$.

As a dispersed reinforcing component (fiber analogue), steel meshes made of steel type A 414 Grade A with square cells with a diameter of $0.8 \mathrm{~mm}$ and a step of $10 \mathrm{~mm}$ were used. A row of meshes with a distance of $4 \mathrm{~mm}$ between them was placed in the mold with a size $16 \times 9 \times 4 \mathrm{~cm}$. Next, a concrete mixture was prepared for the RPC (C 70/85) and placed in the mold. After $24 \mathrm{~h}$ of normal hardening, the specimens were processed and stored for 27 days at a temperature of $(18 \pm 2){ }^{\circ} \mathrm{C}$ and air humidity over $90 \%$ until testing. After that, the specimens were subjected to a flexural tensile test according to the three-point scheme, and a load-strain diagram was also constructed.

Research results. Fig. 1 shows a load-strain diagram for specimen with 10 meshes. As can be seen, the diagram shows a marked «plateau» of the stability of the load with a constant increase in deformation (deflection). Obviously, this indicates the presence of high deformation-plastic properties in the tested specimen.

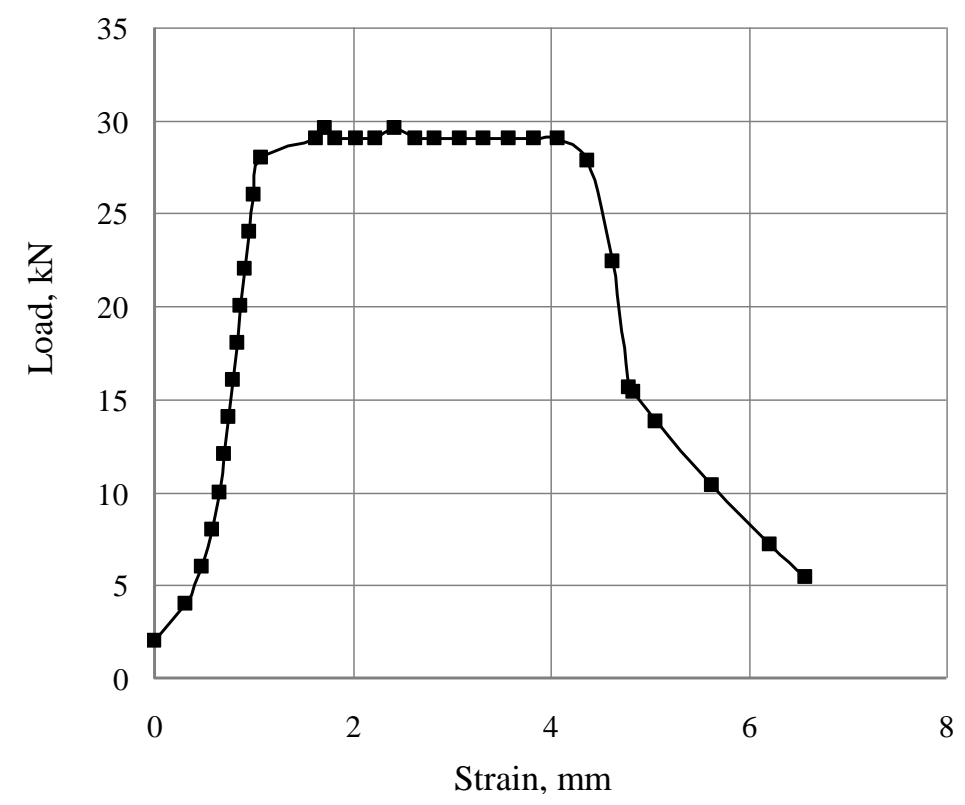

Fig. 1. Load-strain diagram for the RPC specimen with 10 meshes 
To evaluate the result, specimens of similar sizes were made on reactive powder and finegrained concretes, as well as with different contents of mesh and steel fiber (Table 1).

Table 1 - Mesh and dispersed reinforcement of the specimens

\begin{tabular}{|c|c|c|c|c|c|c|c|c|c|}
\hline No. & Specimens (marking) & RPC & FGC & M-3 & M-5 & M-10 & F & FFGC & M-5F \\
\hline 1 & Concrete (matrix) * & RPC & FGC & RPC & RPC & RPC & RPC & FGC & RPC \\
\hline 2 & Number of meshes & - & - & 3 & 5 & 10 & - & - & 5 \\
\hline 3 & $\begin{array}{c}\text { Content of steel mesh, } \\
\mathrm{kg} / \mathrm{m}^{3}\end{array}$ & - & - & 46 & 70 & 140 & - & - & - \\
\hline 4 & $\begin{array}{c}\text { Content of steel fiber, } \\
\mathrm{kg} / \mathrm{m}^{3}\end{array}$ & - & - & - & - & - & 140 & 140 & 70 \\
\hline
\end{tabular}

* RPC - reactive powder concrete; FGC - fine-grained concrete.

As shown with the test results, specimens without dispersed reinforcement (Fig. 2, a) showed rather low values of ultimate deformations (about $0.6 \mathrm{~mm}$, with some preference for reactive powder concrete). The nature of the fracture is fragile. This is shown by almost straight lines in the diagram and was observed visually during the test.

Adding to the composition of the reactive powder and fine-grained concretes of steel fiber leads to the expected increase in flexural tensile strength, but most importantly - there are descending branches on the deformation curves (Fig. 2, b). This indicates an improvement in the deformation properties of concretes due to dispersed fiber reinforcement.

a)

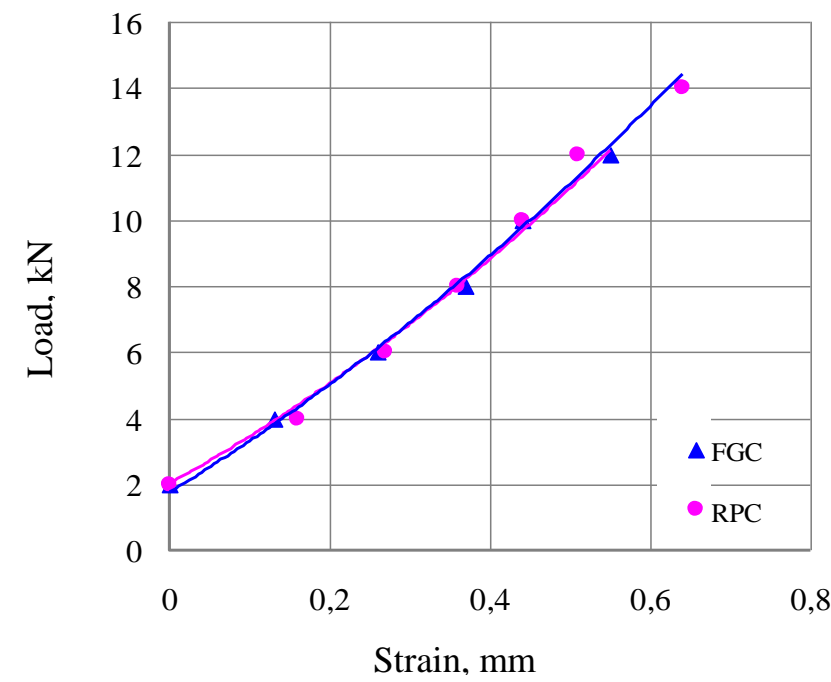

b)

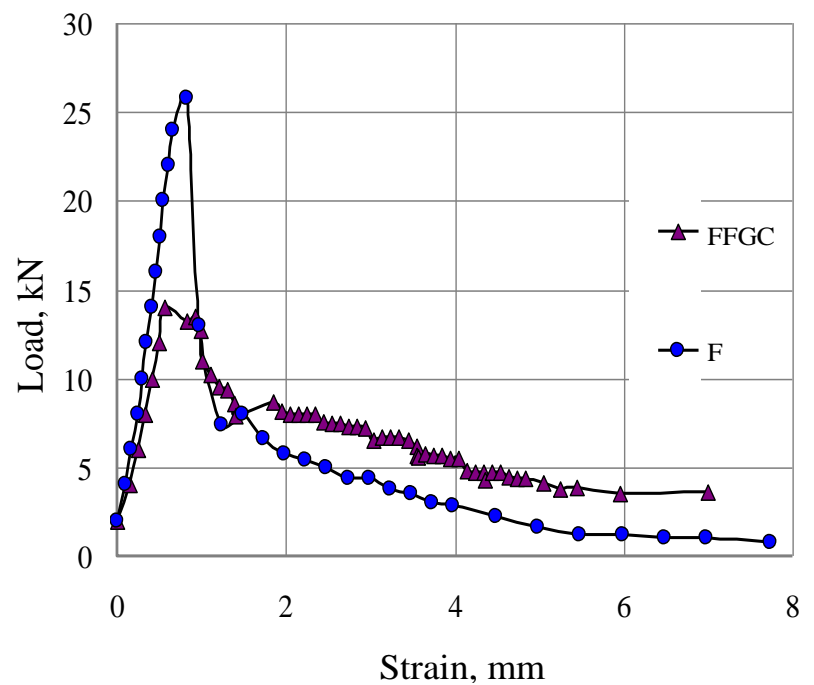

Fig. 2. Load-strain diagram for the reactive powder and fine-grained concrete specimens: $a$ - including steel fiber; $b$ - without steel fiber

The best results for providing high deformation properties of concrete showed specimens containing dispersed reinforcement in the form of meshes. The maximum breaking load is fixed in the specimen containing 10 meshes and is characterized by a pronounced «plateau» of the load constancy with a constant increase in deformation (Fig. 3).

Good results were also demonstrated with a specimen containing 5 meshes and fiber (M-5F). For this specimen, the flexural tensile strength value is even higher than that of the 10-mesh specimen (M-10). At the same time, the descending branches of the strains in the diagram are significantly different, not in favor of the combined reinforcement option. Also different is the nature of the destruction. Specimen M-10 looks less destroyed after the test (Fig. 4). 


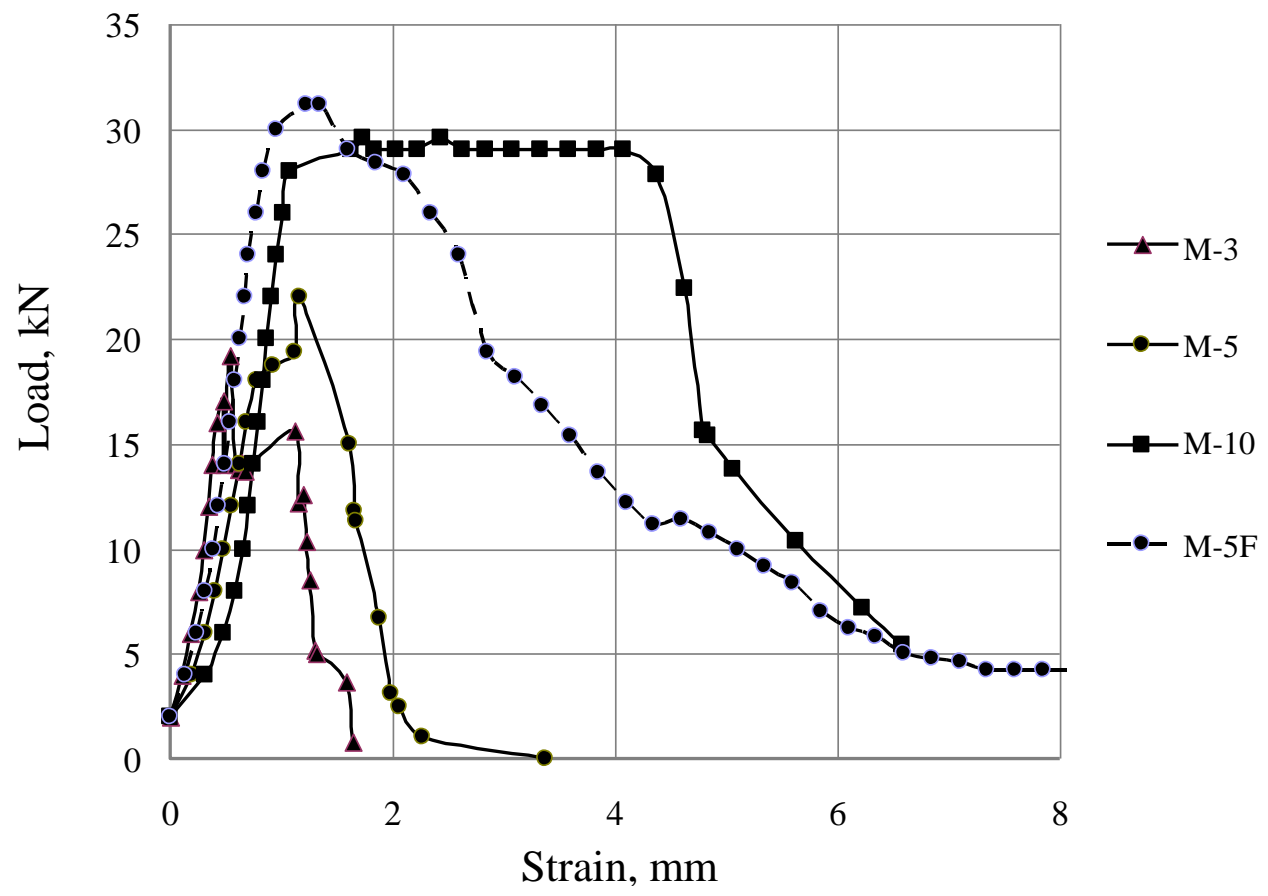

Fig. 3. Load-strain diagram for the reactive powder concrete specimens with different mesh content

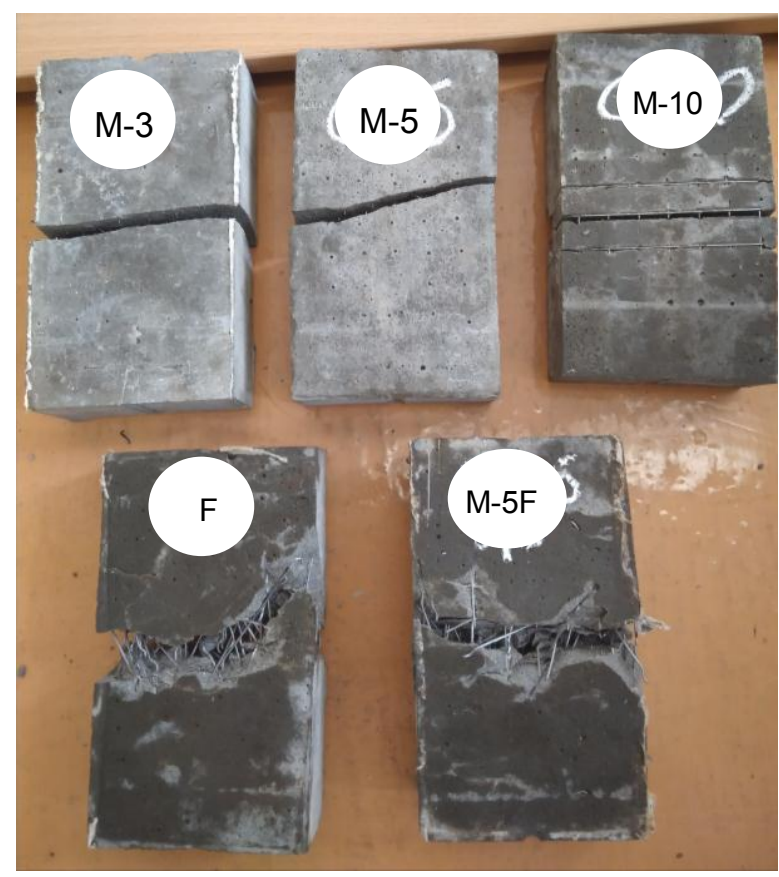

Fig. 4. The appearance of specimens after the test (marking of specimens in accordance with Table 1)

The positive effect of increasing the deformability of concrete due to the use of steel mesh as a dispersed reinforcement is achieved as follows. Steel meshes in the mass of concrete act as analogues of fiber, but, in contrast, have two significant advantages: they allow the joint operation of the entire volume of steel under stresses and are also characterized by the correct orientation relative to the existing external load. As a result, it becomes possible to increase the flexural tensile strength of concrete and increase its plastic deformation significantly.

According to the results of additional studies, the optimal parameters of mesh dispersed reinforcement are as follows: diameter of the mesh rods is $0.8 \ldots 1.2 \mathrm{~mm}$; mesh pitch $10 \ldots 15 \mathrm{~mm}$; 
the distance between the individual meshes $3 \ldots 10 \mathrm{~mm}$; content of mesh in concrete (by weight) $75 \ldots 200 \mathrm{~kg} / \mathrm{m}^{3}$.

The diameter of the mesh rods is taken similarly to the most common diameters of steel fiber. If the diameter is less than $0.8 \mathrm{~mm}$, it is necessary to increase the number of meshes in cross section of the product or structure, and with a diameter of more than $1.2 \mathrm{~mm}$ - the total consumption of steel per volume of concrete increases. A reduction in mesh pitch less than $10 \mathrm{~mm}$ increases the consumption of steel and complicates the molding process, and an increase of more than $15 \mathrm{~mm}$ reduces the efficiency of the reinforcing component.

Reducing the distance between the individual meshes less than $3 \mathrm{~mm}$ complicates the process of fixing them in formwork or form, and also impairs the uniform distribution of the concrete mixture. Increasing the distance of more than $10 \mathrm{~mm}$ results in a «layered» effect of the structure or product, which degrades the deformation properties.

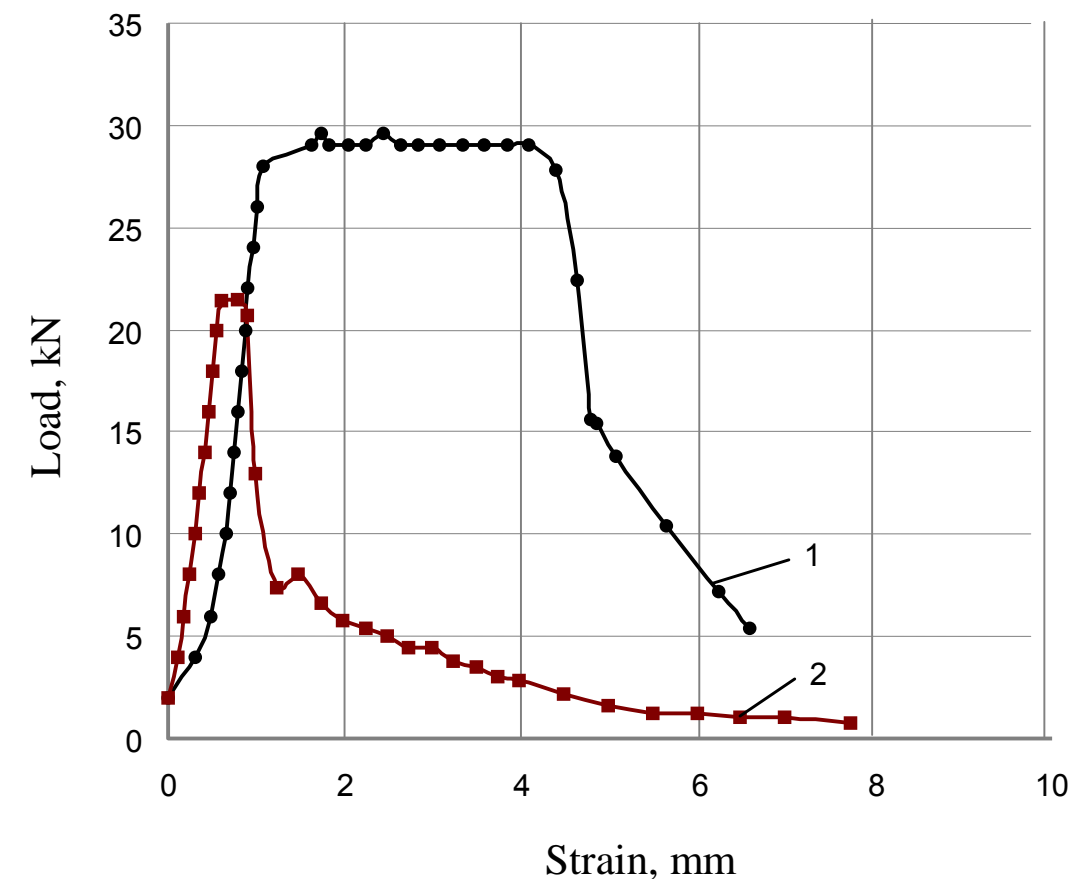

Fig. 5. Load-strain diagram:

1 - RPC specimen with 10 meshes; 2 - reactive powder fiber reinforced concrete

The content of mesh by weight is taken in accordance with the most common consumption of steel fiber in concrete. Reducing the contents below $75 \mathrm{~kg} / \mathrm{m}^{3}$ does not provide the required values of deformative properties, and an increase of more than $200 \mathrm{~kg} / \mathrm{m}^{3}$ leads to a significant increase in the cost of the structure without a corresponding deformability increase.

To determine the effectiveness of dispersed mesh reinforcement, compare the test results of the specimen M-10 with 10 meshes and similar in composition of concrete specimen $\mathrm{F}$ with a fiber content of $140 \mathrm{~kg} / \mathrm{m}^{3}$, which corresponded to the consumption of steel in the specimen M-10.

As can be seen from the diagram (Fig. 5), specimen M-10 has a flexural tensile strength of $32 \mathrm{MPa}$, which is $30 \%$ more than that of a specimen made using fiber ( $25 \mathrm{MPa})$. In addition, plastic deformations increase substantially, increasing almost 5 times $(4 \ldots 4.5 \mathrm{~mm}$ vs. $0.5 \ldots 1 \mathrm{~mm})$, which is reflected in the load-strain diagram.

Conclusions. The proposed method of reinforcing steel at comparable consumption per $1 \mathrm{~m}^{3}$ of concrete can replace at the same time both reinforcement with steel rods and dispersed fiber reinforcement. Dispersed reinforcement of reactive powder concretes with metal meshes with defined parameters can significantly improve their deformation properties, or at the same values significantly reduce the cost of steel in concrete products and structures. Due to the above, a significant economic effect can be achieved. It is also possible to use structures of such concretes in responsible structures with high loads. 


\title{
References
}

[1] Yu.M. Bazhenov, Betonopolimery. M.: Strojizdat, 1983.

[2] A.V. Satalkin, V.A. Solnceva, Cementno-polimernye betony. M.: Strojizdat, 1971.

[3] L.I. Dvorkin, O.L. Dvorkin, Osnovy betonovedeniya. SPb.: Stroj Beton, 2006.

[4] F.N. Rabinovich, Kompozity na osnove dispersnoarmirovannyh betonov. Voprosy teorii i proektirovaniya, tehnologiya, konstrukcii: Monografiya. M.: Izdatelstvo ASV, 2004.

[5] S.V. Klyuev, A.V.Klyuev, N.I. Vatin, "Fiber concrete for the construction industry", Magazine of Civil Engineering, no. 84(8), pp.41-47, 2018. https://doi: 10.18720/MCE.84.4.

[6] K. Holschemacher, T. Mueller, Y. Ribakov, "Effect of steel fibres on mechanical properties of high-strength concrete", Materials and Design, vol. 31, Issue 5, pp. 2604-2615, 2010. https://doi: 10.1016/j.matdes.2009.11.025.

[7] L. Dvorkin, O. Bordiuzhenko, V. Zhitkovsky, V. Marchuk, "Mathematical modeling of steel fiber reinforced concrete properties and selecting its effective composition", Transbud - 2019. IOP Conf. Series: Materials Science and Engineering, no. 708, 012085, 2019. https://doi: 10.1088/1757-899X/708/1/012085.

[8] V.I. Kalashnikov, V.S. Demyanova, V.M. Volodin, A.D. Gusev, "Resursosberegayushie poroshkovye fibrobetony s ispolzovaniem tehnogennyh othodov", Stroitelnye materialy, no. 8. pp. 52-54, 2012.

[9] S. Cao, X. Hou, Q. Rong, W. Zheng, M. Abid, G. Li, "Effect of specimen size on dynamic compressive properties of fiber-reinforced reactive powder concrete at high strain rates", Construction and Building Materials, vol. 194, pp. 71-82, 2019. https://doi: 10.1016/j.conbuildmat.2018.11.024.

[10] D.Y. Yoo, S.T. Kang, Y.S. Yoon, "Effect of fiber length and placement method on flexural behavior, tension-softening curve, and fiber distribution characteristics of UHPFRC", Construction and Building Materials, vol. 64, pp. 67-81, 2014.

\section{ДОСЛІДЖЕННЯ ДЕФОРМАТИВНОСТІ РЕАКЦІЙНО-ПОРОШКОВИХ БЕТОНІВ ІЗ СТАЛЕВИМИ СІТКАМИ}

\author{
${ }^{1}$ Дворкін Л.Й., д.т.н., професор, \\ dvorkin.leonid@gmail.com, ORCID: 0000-0001-8759-6318, \\ ${ }^{1}$ Бордюженко О.М., к.Т.Н., доцент, \\ bord@nwm.edu.ua, ORCID: 0000-0003-3686-5121 \\ ${ }^{1}$ Наиіональний університет водного господарства та природокористування, \\ вул. Соборна, 11, Рівне, 33028, Україна
}

Анотація. Наведено результати досліджень деформативних властивостей реакційнопорошкових бетонів 3 армуванням сталевими сітками, що виступають в ролі упорядковано розташованої дисперсної арматури. Встановлено, що дисперсне армування реакційнопорошкових бетонів сталевими сітками дозволяє суттєво покращити їх деформаційні властивості або при тих же значеннях суттєво знизити витрати сталі у бетонних виробах $\mathrm{i}$ конструкціях.

Реакційно-порошкові фібробетони мають досить високі значення граничних деформацій. Однак подальшого покращення цих властивостей досягнути досить важко. Це пояснюється складністю орієнтованого розташування сталевого волокна в масиві бетону паралельно виникаючим напруженням при розтягу та нездатністю окремих волокон працювати спільно.

Збільшення значень деформативних властивостей бетону, а саме границі міцності на розтяг при згині та граничних деформацій бетону можна досягнути, якщо використовувати в якості армуючого компонента, сталеві сітки, які розташовують в бетоні перпендикулярно діючим навантаженням (паралельно виникаючим розтягуючим напруженням). Сталеві сітки можна розглядати як аналог упорядковано розташованої дисперсної арматури.

Сталеві сітки в масі бетону виступають аналогами дисперсного волокна, але, на противагу йому, мають дві суттєві переваги: вони забезпечують спільну роботу всього 
об'єму сталі при виникаючих напруженнях, а також характеризуються правильною орієнтацією відносно існуючого зовнішнього навантаження. В результаті можна суттєво підвищити міцність на розтяг бетону та збільшити його пластичні деформації.

Дисперсне армування реакційно-порошкових бетонів металевими сітками з визначеними параметрами дозволяє суттєво покращити їх деформаційні властивості, або при тих же значеннях суттєво знизити витрати сталі у бетонних виробах і конструкціях. За рахунок вищесказаного може досягатися значний економічний ефект. Також стає можливим конструкції iз таких бетонів застосовувати у відповідальних спорудах, що піддаються значним навантаженням.

Ключові слова: реакційно-порошковий бетон, дисперсне армування, сталеві сітки, фібра, деформативність.

\title{
ИССЛЕДОВАНИЕ ДЕФОРМАТИВНОСТИ РЕАКЦИОННО-ПОРОШКОВЫХ БЕТОНОВ СО СТАЛЬНЫМИ СЕТКАМИ
}

\author{
${ }^{1}$ Дворкин Л.И., д.т.н., профессор, \\ dvorkin.leonid@gmail.com, ORCID: 0000-0001-8759-6318 \\ ${ }_{1}^{1}$ Бордюженко О.М., к.т.н., доцент, \\ bord@nwm.edu.ua, ORCID: 0000-0003-3686-5121 \\ ${ }^{1}$ Национальный университет водного хозяйства и природопользования, \\ ул. Соборная, 11, Ровно, 33028, Украина
}

Аннотация. Приведены результаты исследований деформативных свойств реакционнопорошковых бетонов с армированием стальными сетками, выступающими в роли упорядоченно расположенной дисперсной арматуры. Установлено, что дисперсное армирование реакционно-порошковых бетонов стальными сетками позволяет существенно улучшить их деформационные свойства или, при тех же значениях, существенно снизить расход стали в бетонных изделиях и конструкциях.

Реакционно-порошковые фибробетоны имеют достаточно высокие значения предельных деформаций. Однако дальнейшего улучшения этих свойств достичь достаточно трудно. Это объясняется сложностью ориентированного расположения стального волокна в массиве бетона параллельно возникающим напряжением при растяжении и неспособностью отдельных волокон работать совместно.

Увеличение значений деформативных свойств бетона, а именно предела прочности на растяжение при изгибе и предельных деформаций бетона можно достичь, если использовать в качестве армирующего компонента, стальные сетки, располагаемые в бетоне перпендикулярно действующим нагрузкам (параллельно возникающим растягивающим напряжениям). Стальные сетки можно рассматривать как аналог упорядоченно расположенной дисперсной арматуры.

Стальные сетки в массиве бетона выступают аналогами дисперсного волокна, но, в противовес ему, имеют два существенных преимущества: они обеспечивают совместную работу всего объема стали при возникающих напряжениях, а также характеризуются правильной ориентацией относительно существующей внешней нагрузки. В результате становится возможным существенно повысить прочность бетона на растяжение и увеличить его пластические деформации.

Дисперсное армирование реакционно-порошковых бетонов металлическими сетками с определенными параметрами позволяет существенно улучшить их деформационные свойства, или при тех же значениях существенно снизить расход стали в бетонных изделиях и конструкциях. За счет вышесказанного может достигаться значительный экономический эффект. Также становится возможным применять конструкции из таких бетонов в ответственных сооружениях, подвергающихся значительным нагрузкам.

Ключевые слова: реакционно-порошковый бетон, дисперсное армирование, стальные сетки, фибра, деформативность.

Стаття надійшла до редакції 06.05.2020 